\title{
PENGARUH FAKTOR FUNDAMENTAL DAN RISIKO SUSTEMATIK TERHADAP HARGA SAHAM SEKTOR PROPERTI DI BURSA EFEK INDONESIA TAHUN 2008-2012
}

\author{
Yunavita Uzzic Elsanti \\ uzzic.zzzt agmail.com \\ Fitri Lukiastuti \\ faluki@yahoo,com \\ Setyo Pantawis \\ setyowish@gmail.com \\ STIE BDP Semarang \\ Riwayat Artikel: dikirim Oktober 2018, diterima September 2018, diterbitkan September 2018 \\ Abstract
}

Ineming in property is included in the investment sector which has a high risk becatuse the property is ary satitive 10 macroeconomic conditions. Therefore property share prices in the stock market is very Fundamental analysis and systematic risk is one step that can be used before investing perty sector. For this study it was established with the aim to find out and obtain ampical evidence about the fundamental and systematic risk factors that affect the stock price of the ziropery. Fundamental factors used are NPM, ROA, ROE, EPS, DER, BVS and Systematic Risk represented by the Beta. This study used purposive sampling to select a sample of the population of the properties listed companies on the Stock Exchange from 2008-2012. The data analysis technique used is multiple linear regression. The results showed that the only variable that ROA has a positive influence on the share price of the property, while the variable NPM, ROE, DER, EPS, BVS and Systematic Risk does not have an influence on the stock price of the property. Adjusted R2 value in this study was $25 \%$.

Keywords : Fundamental Factors, Systematic Risk, Stock Price 


\section{Pendahuluan}

Pada tahun 2008 hampir seluruh negara di dunia mengalami krisis perekonomian. Krisis global yang mucul pertama kali di Amerika itu bermula dari bisnis properti Amerika Serikat yang disebut Subprime Mortgage. Subprime Mortage sendiri adalah sebutan untuk program pemberian kredit rumah murah (mortgage) atau KPR yang ditujukan untuk kalangan menengah kebawah (subprime) yang belum pernah memiliki atau melakukan kredit rumah sebelumnya. (http://finance.detik.com, 15 April 2009). Program yang bertujuan memberikan rumah murah untuk rakyat miskin ini justru menjadi boomerang bagi pemerintah Amerika Serikat sendiri. Subprime Mortgage bermula dari salah suatu perusahaan properti yang berhasil mendapatkan profit besar dari bisnis perumahan murah. Melihat prospek yang menjanjikan dalam bisnis tersebut, membuat pengusaha properti lain berlomba-lomba memberikan rumah dengan harga murah. Perbankan pun ikut mecari keuntungan dari bisnis tersebut dengan memberikan kredit kepada perusahaan-perusahaan properti. Dengan bertambahnya modal yang didapat, membuat perusahaan makin menambah pembangunan rumah dan akhirnya jumlah rumah yang ditawarkan justru melebihi kebutuhan masyarakat. Akibatnya banyak unit rumah yang tidak terjual, harga rumah jatuh, dan akhirnya membuat perusahaan tidak mampu membayar kepada pihak bank.

Untuk mengatasi kejadian ini, perusahaan mencoba mencari keuntungan di dalam pasar saham global dengan menjual sekuritas perusahaan. Menurut http://finance.detik.com (15 April 2009), pada tahap pertama, sekuritisasi dilaksanakan terhadap sejumlah subprime mortgage sehingga menjadi sekuritas yang disebut mortgage-backed securities (MBS). Perdagangan sekuritas ini membuat kesalahan dengan mengemas sekuritas MBS dengan sekuritas lain dan menjualnya kembali dengan nama yang berbeda. Kejadian ini terus berulang yang akhirnya mengakibatkan harga saham properti pun anjlok.

Masalah ini membuat perusahaan properti maupun perbankan mengalami kerugian besar yang berujung pada hancurnya perekonomian Amerika Serikat. Harga saham perusahaan Amerika di Wall Street anjlok. dan banyak investor yang menarik uang mereka dari pasar saham negara lain untuk dapat membayar hutang. Selama ini negara Amerika menjadi patokan utama negara lain dalam perdagangan, karena dasar transaksi perdagangan menggunakan dollar Amerika (US\$). Dengan memburuknya kondisi perekonomian negara Amerika otomatis negara lain akan merasakan dampaknya. Perusahan properti di kawasan Eropa Amerika mengalami penurunan besarbesaran. Seperti negara Inggris yang harga propertinya mengalami penurunan dan mengakibatkan 600.000 orang lebih kehilangan pekerjaannya.

Disaat bisnis properti di negara Amerika Serikat dan Eropa mengalami krisis, sebaliknya yang terjadi di Indonesia. Berdasarkan data dari majalah Infobank (Oktober, 2012: 40)

"Pertumbulian ekonomi Indonesia selama 2012 cukup menggembirakan. Badai krisis dari daratan Eropa tidak begitu berpengaruh terhadap kekuatan ekonomi Indonesia. Bahkan, hampir semua sektor ekonomi tumbuh positif, termasuk sektor properti. Selama kuartal pertama 2012 kinerja penjualan produk properti di Indonesia menjadi sorotan di kawasan Asia Pasifik karena melaju kencang saat penjualan produk properti di Asia Pasifik terseok-seok akibat ketidakpastian kondisi ekonomi global. Hasil riset konsultan properti Knight Frank, menyebutkan, kinerja sektor properti Indonesia pada kuartal pertama 2012 terkuat di Asia Pasifik. Pertumbuhannya bahakan meninggalkan Malaysia, India, China, Selandia Baru, Korea Selatan, juga Australia."

Perusahaan properti Indonesia menjadi incaran para investor Amerika dan Eropa. Hal ini disebabkan kondisi ekonomi Indonesia yang tidak terlalu terpengaruh oleh krisis global bahkan cenderung naik. Selain itu rakyat Indonesia yang semakin sadar akan arti investasi, lebih banyak memilih investasi pada aset properti seperti rumah, apartemen, ruko, dIl. Investasi pada aset properti dirasa lebih memberikan keuntungan yang besar daripada investasi melalui deposito, yang memiliki bunga kecil dan potongan pajak yang besar.

Investasi pada properti bukan hanya pada wujud properti itu sendiri (rumah. apartemen, ruko) melainkan juga pada saham 
perusahaan properti. Tingginya permintaan akan properti membuat harga properti ikut naik, tentu saja harga saham perusahaan properti pada pasar saham juga mengalami kenaikan. Fenomena booming properti yang terjadi di Indonesia mulai dari tahun 2011 akhir hingga tahun 2012 dan berlanjut hingga saat ini, membuat hampir semua saham properti naik. Kondisi ini menunjukkan banyak investor yang percaya dengan saham sektor properti, bukan hanya investor dari Indonesia saja bahkan investor asing juga ikut menanamkan modalnya pada saham properti di Indonesia.

Investasi pada dasarnya hanya memperhatikan dua hal, yaitu berapa besar return yang diperoleh dan seberapa tinggi risiko yang dihadapi. Maka dari itu muncul istilah dalam masyarakat $\mathrm{High}$ Risk High Return, semakin tinggi risiko yang dihadapi maka semakin besar return yang akan diperoleh. Return saham dapat dianalisis dengan cara analisis fundamental. Analisis fundamental adalah analisis untuk mengetahui kondisi emiten, pertumbuhan industri dan aspek makro suatu negara. Dengan mengetahui kondisi emiten, pertumbuhan industri dan aspek makro suatu negara diharapkan dapat diketahui kondisi fundamental investasi pada saham tertentu sehingga dapat dihitung nilai intrinsik (intrinsic value) suatu saham (Susilo, 2009: 63).

Analisis fundamental dilakukan dengan mengamati tiga hal, yang pertama kondisi fundamental perusahaan. Kondisi fundamental perusahaan dapat dilihat dari rasio keuangannya, dimana dalam penelitian ini menggunakan rasio keuangan NPM $\mathrm{Net}$ Profit Margin), ROA (Return On Asset), ROE (Return On Equity), EPS (Earning Per Share), BVS (Book Value Per Share), dan DER (Debt To Equity Ratio). Kedua, kondisi industri dimana dalam hal ini adalah industri properti. Kondisi industri properti dilakukan dengan menghitung rata-rata industri. Data tersebut dapat membantu investor untuk melihat apakah perusahaan tersebut baik atau tidak dengan membandingkan rasio keuangan per perusahaan dengan rasio keuangan industri. Ketiga, kondisi makro ekonomi Indonesia, Keadaan ekonomi makro Indonesia sangat mempengaruhi kondisi perusahaan, misalnya seperti nilai tukar rupiah terhadap dollar, tingkat inflasi, perekonomia Indonesia, nilai ekspor impor, dan masih banyak lagi. (Susilo, 2009; 64)

Selain return investor harus memperhitungkan seberapa tinggi risiko yang dihadapi. Menurut Kodrat dan Indonanjaya (2010: 263), risiko terdiri dari dua yaitu risiko unsistematik (unsystematic risk) dan risiko sistematik (systematic risk). Risiko unsistematik (unsystematic risk) adalah risiko yang dapat dihilangkan melalui diversifikasi. Risiko ini merupakan probabilitas keuntungan berada di bawah keuntungan yang diharapkan yang disebabkan oleh faktor-faktor yang hanya ada pada satu perusahaan. Sedangkan risiko sistematik (systematic risk) adalah risiko yang tidak dapat dihilangkan melalui diversifikasi. Risiko ini sering disebut risiko pasar (market $r i s k$ atau risiko sistematik karena faktor ini terjadi pada seluruh ekonomi atau pasar. Risiko yang paling besar dan harus diperhatikan oleh investor adalah risiko sistematik, karena risiko ini berasal dari kondisi makro ekonomi dan tidak dapat dihindari. Risiko biasanya dinyatakan dengan Beta. Menurut Jogiyanto (2009: 365) Beta dibedakan menjadi tiga, yaitu beta pasar yang digunakan untuk melihat pengaruh kondisi pasar terhadap harga saham, beta akuntansi untuk melihat pengaruh kondisi laba akuntansi perusahaan terhadap harga sabam, dan beta fundamental yang fungsinya untuk melihat pengaruh kondisi fundamental perusahaan terhadap harga saham. Dalam penelitian ini menggunakan beta pasar karena peneliti ingin melihat pengaruh kondisi pasar terhadap harga saham. Beta pasar dapat diestimasi dengan mengumpulkan nilai-nilai historis return dari sekuritas dan return dari pasar selama periode tertentu, dengan asumsi bahwa hubungan antara return-return sekuritas dan return-return pasar adalah linier. (Jogiyanto, 2009: 365),

Dengan melakukan langkah-langkah analisis tersebut, investor bisa mengetahui bagaimana kondisi fundamental perusahaan dan risiko sistematik dapat mempengaruhi suatu harga saham, baik untuk saat ini maupun untuk masa mendatang. Dengan begitu imestor dapat memperkirakan saham apa yang sebaiknya ia beli. Pengaruh analisis fundamental dan risiko sistematik terhadap harga saham juga telah terbukti pada beberapa penelitian yang telah dilakukan sebel-ayz. Penclitian yang dilakukan oleh Yusi (Q)il) menyimpulkan bahwa Beta, 
DER, dan ROA memiliki pengaruh terhadap harga saham. Namun, berbeda denga penelitian yang dilakukan oleh Anwar (2008) dimana disimpulkan bahwa Beta tidak memiliki pengaruh terhadap harga saham. Uli (2008) menyatakan DER tidak memiliki pengaruh terhadap harga saham, dan Stella (2009) menyatakan ROA tidak berpengaruh terhadap harga saham.

Penelitian yang dilakukan oleh Ritonga dan Akhmad (2012) menyatakan bahwa BVS dan EPS memiliki pengaruh terhadap harga saham. Sebaliknya, Nirohito (2009) menyatakan bahwa BVS tidak memiliki pengaruh terhadap harga saham, dan Anwar (2008) menyatakan bahwa EPS tidak memiliki pengaruh terhadap harga saham. Pasaribu (2008) menyatakan rasio profitabilitas yang diukur dengan NPM memiliki pengaruh terhadap harga saham, sedangkan ROE tidak berpengaruh terhadap harga saham. Penelitian ini berbeda dengan yang dilakukan oleh Anwar (2008) dimana NPM memiliki pengaruh terhadap harga saham, dan penelitian yang dilakukan Tanjung dan Darlis (2009) dimana ROE memiliki pengaruh terhadap harga saham.

Berdasarkan latar belakang yang telah diuraikan sebelumnyam, maka rumusan masalah dalam penelitian ini adalah sebagai berikut:

1) Apakah NPM memiliki pengaruh positif terhadap Harga Saham?

2) Apakah ROA memiliki pengaruh positif terhadap Harga Saham?

3) Apakah ROE memiliki pengaruh positif terhadap Harga Saham?

4) Apakah EPS memiliki pengaruh positif terhadap Harga Saham?

5) Apakah DER memiliki pengaruh negatif terhadap Harga Saham?

6) Apakah BVS memiliki pengaruh positif terhadap Harga Saham?

7) Apakah Risiko Sistematik memiliki pengaruh positif terhadap Harga Saham?

2. Metode Penelitian

Populasi dalam penelitian ini adalah seluruh perusahaan properti (sektor properti dan real estate) yang telah dan masih terdaftar dari tahun 2008 sampai dengan tahun 2012 di $\mathrm{BEI}$, sebanyak 55 perusahaan. Dari populasi tersebut diperoleh sampel sebanyak 34 perusahaan. Pemilihan sampel menggunakan metode purposive sampling, dengan kriteria sebagai berikut:
1) Perusahaan properti (sektor properti dan real estate) yang sudah dan masih terdaftar dari tahun 2008 sampai dengan tahun 2012 di Bursa Efek Indonesia.

2) Perusahaan properti (sektor properti dan real estate) yang memiliki laporan keuangan lengkap dan telah melaporkannya ke Bursa Efek Indonesia setiap tahun (dari tahun 2008. 2012).

3) Perusahaan properti (sektor properti dan real estate) yang melakukan transaksi di bursa saham setiap tahun (dari tahun 2008-2012).

Variabel-variabel yang akan diteliti terdiri dari variabel dependen ( $\mathrm{Y}$ ), yaitu harga saham. Harga saham yang digunakan adalah harga saham penutupan setiap akhir bulan. Variabel independen yang digunakan: NPM $\left(X_{1}\right)$, ROA $\left(X_{2}\right)$, ROE $\left(X_{3}\right)$, EPS $\left(X_{4}\right)$, DER $\left(X_{5}\right)$, BVS $\left(X_{6}\right)$, dan Risiko Sistematik $\left(X_{7}\right)$.

NPM merupakan rasio yang menggambarkan kemampuan perusahaan dalam menghasilkan laba bersih. Menghitungnya dengan membagi laba bersih dengan total penjualan. (Susilo, 2009: 70), NPM dapat dihitung dengan rumus:

$$
N P M=\frac{\text { laba bersih }}{\text { penjualan bersih }}
$$

ROA merupakan rasio yang
mengukur menghasilkan laba bersih berdasarkan tingkat aset tertentu. (Hanafi dan Halim, 2009: 84). ROA dapat dihitung dengan rumus:

$$
\text { ROA }=\frac{\text { laba bersih }}{\text { total } \text { asset }}
$$

ROE sering disebut dengan rate of return on Net Worth yaitu kemampuan perusahaan dalam menghasilkan keuntungan dengan modal sendiri yang dimiliki, sehingga ROE ini ada yang menyebut rentabilitas modal sendiri. Laba yang diperhitungkan adalah laba bersih setelah dipotong pajak atau EAT. (Sutrisno, 2009: 223). ROE dapat dihitung dengan rumus:

$$
\text { ROE }=\frac{\text { laba bersih }}{\text { total ekuitas }}
$$

DER menunjukkan sejauh mana modal sendiri menjamin seluruh utang. (Hidayat, 2011: 121). DER dapat dihitung dengan rumus:

$$
D E R=\frac{\text { total hutang }}{\text { total ekuitas }}
$$


EPS merupakan tingkat keuntungan bersih untuk tiap lembar sahamnya yang mampu diraih perusahaan pada saat menjalankan operasinya yang dihitung dengan melakukan perbandingan antara pemdapatan bersih setelah pajak (net income after tax, NIAT) dengan jumlah saham yang diterbitkan. (Hidayat, 2011: 125). EPS dapat dihitung dengan rumus:

$$
\begin{aligned}
& \text { EPS } \\
& =\frac{\text { net income after tax }}{\text { jumlah seluruh saham diterbitkan }}
\end{aligned}
$$

BVS digunakan untuk mengukur nilai modal pemegang saham untuk setiap saham. (Hidayat, 2011: 126). BVS dapat dihitung dengan rumus:

$$
\text { BVS }=\frac{\text { total shareholder's equity }}{\text { jumlah saham diterbitkan }}
$$

Risiko sistematis (systematis risk) adalah risiko yang tidak dapat dihilangkan melalui diversifikasi. Risiko ini sering disebut risiko pasar (market risk) atau risiko sistematis karena faktor ini terjadi pada seluruh ekonomi atau pasar. (Kodrat dan Indonanjaya, 2010: 264). Risiko sistematik diukur dengan menggunakan Beta. Beta merupakan suatu pengukur volatilitas (volatility) rettrin suatu sekuritas atau return portofolio terhadap return pasar. Beta sekuritas $\mathrm{ke}-\mathrm{i}$ mengukur volatilitas return sekuritas ke-i dengan return pasar. Beta portofolio mengukur volatilitas return portofolio dengan return pasar. Dengan demikian Beta merupakan pengukur risiko sistematik (systematic risk) dari suatu sekuritas atau portofolio relatip terhadap risiko pasar. Beta suatu sekuritas dapat dihitung dengan teknik estimasi yang menggunakan data historis. Beta dapat diformulasikan sebagai berikut: (Jogiyanto, 2009:367).

$$
R i=\alpha i+\beta i \cdot R_{M}+e_{i}
$$

Berdasarkan penelitian terdahulu, penelitian yang dilakukan oleh Yusi (2011) menyimpulkan bahwa Beta, DER, dan ROA memiliki pengaruh terhadap harga saham. Namun, berbeda denga penelitian yang dilakukan oleh Anwar (2008) dimana disimpulkan bahwa Beta tidak memiliki pengaruh terhadap harga saham. Uli (2008) menyatakan DER tidak memiliki pengaruh terhadap harga saham, dan Stella (2009) menyatakan ROA tidak berpengaruh terhadap harga saham.

Penelitian yang dilakukan oleh Ritonga dan Akhmad (2012) menyatakan bahwa BVS dan EPS memiliki pengaruh terhadap harga saham. Sebaliknya, Nirohito (2009) menyatakan bahwa BVS tidak memiliki pengaruh terhadap harga saham, dan Anwar (2008) menyatakan bahwa EPS tidak memiliki pengaruh terhadap harga saham. Pasaribu (2008) menyatakan rasio profitabilitas yang diukur dengan NPM memiliki pengaruh terhadap harga saham, sedangkan ROE tidak berpengaruh terhadap harga saham. Penelitian ini berbeda dengan yang dilakukan oleh Anwar (2008) dimana NPM memiliki pengaruh terhadap harga sabam, dan penelitian yang dilakukan Tanjung dan Darlis (2009) dimana ROE memiliki pengaruh terhadap harga saham. Maka hipotesis dalam penelitian ini adalah sebagai berikut:

$\mathrm{H}_{0}: \quad \mathrm{ii}=0$, artinya variabel independen (bebas) secara parsial tidak berpengaruh terhadap Harga Saham.

$\mathrm{H}_{\mathrm{a}}(1): \beta \mathrm{i}>0$, artinya variabel NPM secara parsial berpengaruh positif terhadap Harga Saham.

$\mathrm{H}_{\mathrm{a}}(2): \beta \mathrm{i}>0$, artinya variabel $\mathrm{ROA}$ secara parsial berpengaruh positif terhadap Harga Saham.

$H_{\Delta}$ (3) : $\beta i>0$, artinya variabel $R O E$ secara parsial berpengaruh positif terhadap Harga Saham.

$\mathrm{H}_{n}(4): \beta i>0$, artinya variabel EPS secara parsial berpengaruh positif terhadap Harga Saham.

$H_{\mathrm{a}}(5): \beta \mathrm{i}<0$, artinya variabel DER secara parsial berpengaruh negatif terhadap Harga Saham.

$\mathrm{H}_{\mathrm{a}}$ (6): $\beta \mathrm{i}>0$, artinya variabel $\mathrm{BVS}$ secara parsial berpengaruh positif terhadap Harga Saham.

$\mathrm{H}_{\mathrm{a}}(7): \beta \mathrm{i}>0$, artinya variabel Risiko Sistematik secara parsial berpengaruh positif terhadap Harga Saham.

Ho diterima jika angka signifikansinya lebih besar dari $\alpha=5 \%$. Sedangkan Ho ditolak jika angka signifikansinya lebih kecil dari $\alpha=5 \%$ 
Penelitian ini menggunakan alat analisis uji asumsi klasik yang terdiri dari uji normalitas, uji multikoliearitas, uji heteroskedastisitas, dan uji autokorelasi. Regresi linear berganda, serta uji kebaikan model (goodnes of fit) yang terdiri dari koefisien determinasi, uji F, dan uji t.

\section{Hasil dan Pembahasan}

Data yang digunakan pada awalnya menunjukkan bahwa data tersebut tidak normal, oleh karena itu peneliti melakukan transformasi data pada salah satu variabel yaitu harga saham menjadi bilangan logaritma natural $(\mathrm{Ln})$ dengan tujuan agar datanya normal. Setelah diubah menjadi bilangan logaritma natural, data yang digunakan menjadi normal dan lolos uji asumsi klasik.

Tabel 4.9

Hasil Uji Statistik t (Uji t)

Sumber: Data sekunder yang diolah, 2013
Persamaan regresi linear berganda dalam penelitian ini adalah sebagai berikut:

Harga Saham $=4,850-0,080$

$\mathrm{NPM}+13,041 \mathrm{ROA}-2,188 \mathrm{ROE}+0,000$

$\mathrm{EPS}+0,000 \mathrm{BVS}+0,150 \mathrm{DER}+0,11$ Risiko Sistematik

Hasil uji koefisien determinasi menunjukkan nilai adjusted $\mathrm{R}^{2}$ sebesar 0,255 . Itu artinya variabel dependen yaitu Harga Saham dapat dijelaskan oleh variabel independen yang terdiri dari NPM, ROA, ROE, EPS, BVS, DER dan Risiko Sistematik sebesar $25 \%$, sedangkan sisanya $75 \%$ dipengaruhi oleh faktor-faktor diluar variabel yang diteliti.

Uji F yang dilakukan menunjukkan, nilai $F$ sebesar 9,264 dengan nilai signifikansi sebesar 0,000 . Karena nilai signifikansi lebih kecil dari 0,05 maka data yang digunakan dalam penelitian ini layak digunakan karena lolos uji kebaikan model (goodnes of fii).

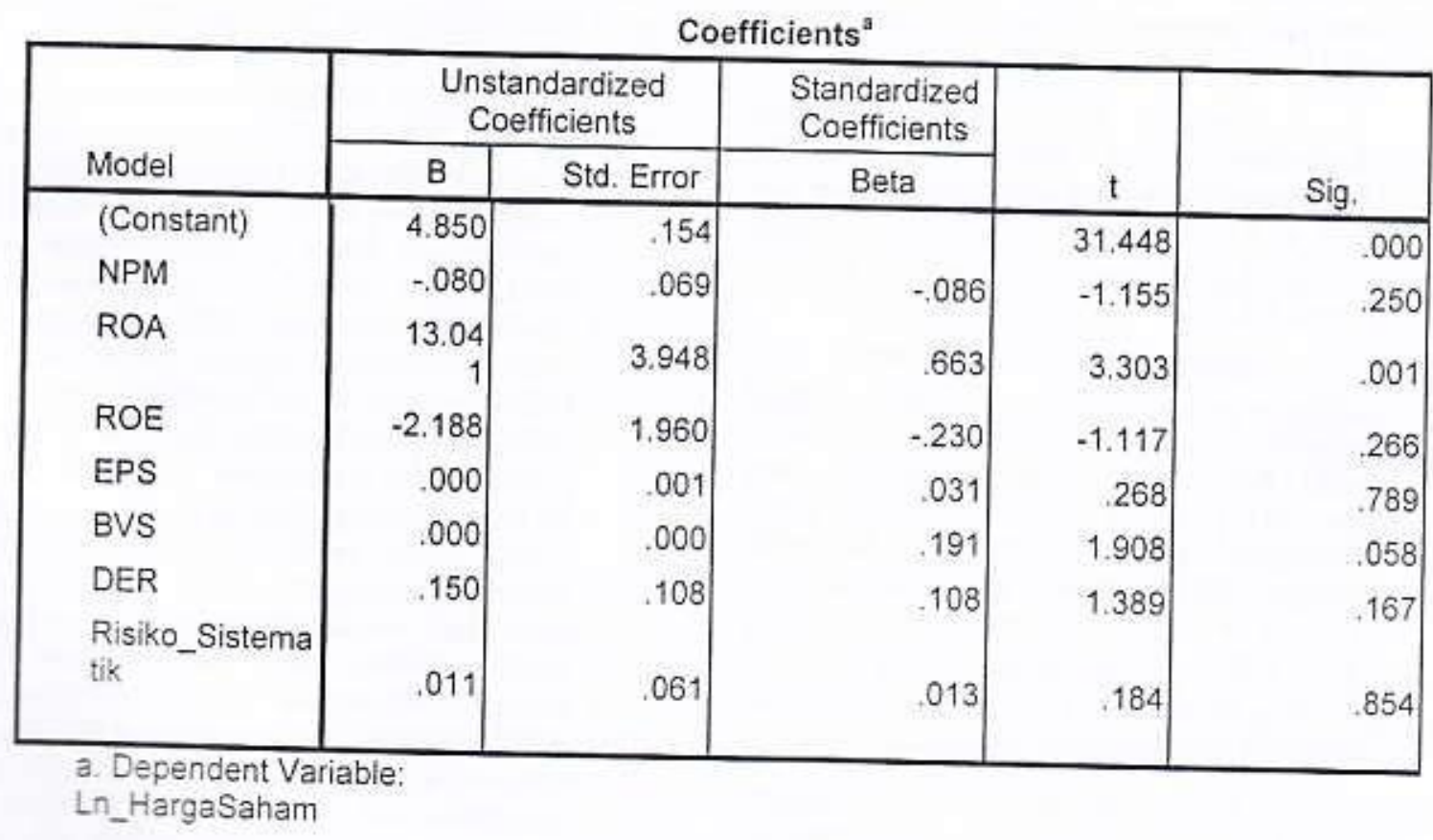


Hasil uji t yang dapat dilihat melalui tabel 4.9 maka hasil hipotesis yang diperoleh adalah sebagai berikut:

variabel NPM yang memiliki nilai signifikansi 0,250 yang artinya lebih besar dari $0,05(0,250>0,05)$. Maka variabel NPM tidak memiliki pengaruh terhadap Harga Saham. Oleh karena itu $\mathrm{H}_{1}$ ditolak.

Variabel ROA memiliki nilai signifikansi sebesra 0,001 yang artinya lebih kecil dari $0,05(0,001<0,05)$. Maka variabel ROA memiliki pengaruh terhadap Harga Saham. Oleh karena itu $\mathrm{H}_{2}$ diterima.

Variabel ROE memiliki nilai signifikansi 0,266 yang artinya lebih besar dari $0,05(0,266>0,05)$. Maka variabel $\mathrm{ROE}$ tidak memiliki pengaruh terhadap Harga Saham. Oleh karena itu $\mathrm{H}_{3}$ ditolak.

Variabel EPS memiliki nilai signifikansi 0,789 yang artinya lebih besar dari $0,05(0,789>0,05)$. Maka variabel EPS tidak memiliki pengaruh terhadap Harga Saham. Oleh karena itu $\mathrm{H}_{4}$ ditolak.

Variabel DER memiliki nilai signifikansi 0,167 yang artinya lebih besar dari $0,05(0,167>0,05)$. Maka variabel DER tidak memiliki pengaruh terhadap Harga Saham. Oleh karena itu $\mathrm{H}_{5}$ ditolak.

Variabel BVS memiliki nilai signifikansi 0,058 yang artinya lebih besar dari $0,05(0,058>0,05)$. Maka variabel BVS tidak memiliki pengaruh terhadap Harga Saham. Oleh karena itu $\mathrm{H}_{6}$ ditolak.

Variabel Risiko Sistematik yang dinyatakan dengan Beta, memiliki nilai signifikansi 0,854 yang artinya lebih besar dari $0,05(0,854>0,05)$. Maka variabel Risiko Sistematik tidak memiliki pengaruh terhadap Harga Saham. Oleh karena itu $\mathrm{H}_{7}$ ditolak.

Berdasarkan hasil uji t yang telah dilakukan, diketahui bahwa dari tujuh variabel penelitian yang digunakan hanya satu variabel yaitu Return On Assets (ROA) saja yang memiliki pengaruh terhadap Harga Saham. Sedangkan variabel lainnya seperti Net Profit Margin (NPM), Retwh On Equity (ROE), Earning Per Share (EPS), Debt To Equity Ratio (DER), Book Vahe Per Share (BVS), Risiko Sistematik (Beta) tidak memiliki pengaruh terhadap Harga Saham.

Hasil penelitian yang menunjukkan bahwa hanya variabel ROA yang memiliki pengaruh terhadap harga saham, dipengaruhi oleh krisis ekonomi global yang terjadi di Amerika Serikat dan Eropa yang memberi dampak terhadap perekonomian Indonesia dan kinerja keuangan perusahaan properti. Rasio keuangan dinyatakan memiliki pengaruh terhadap harga saham jika kondisi internal maupun eksternal perusahaan dalam keadaan normal. Namun dalam kasus ini krisis global yang terjadi menyatakan jika kondisi eksternal perusahaan sedang dalam keadaan tidak normal. Kondisi ini membuat perusahaan properti membuat skala prioritas yaitu dengan mempertahankan penjualan aset properti. Skala prioritas tersebut dibuat agar perusahaan tetap bisa bertahan dalam kondisi yang tidak normal karena terjadinya krisis global. Salah satu akibat dari kondisi ekonomi yang berfluktuasi adalah dengan menurunnya daya beli masyarakat, oleh karena itu perusahaan membuat beberapa penyesuaian dalam penjualan aset properti agar masyarakat yang memiliki daya beli rendah masih dapat membeli rumah atau aset properti lainnya. Beberapa penyesuaian yang dilakukan antara lain dengan memberikan promo-promo seperti gratis PPN dan BPHTB (Bea Perolehan Hak Tanah Bangunan), gratis furniture rumah gratis atau mendapatkan cash back, dll.

Dengan begitu perusahaan properti tetap terus mendapatkan pendapatan dari penjualan unit properti. Dengan mempertahankan penjualan aset properti melalui penawaran-penawaran yang diberikan membuat perusahaan mampu bertahan dalam kondisi ekonomi yang tidak normal, sehingga dapat menaikkan nilai ROA perusahaan.

Rasio keuangan perusahaan sendiri memiliki keterkaitan satu sama lain, jika nilai ROA naik maka rasio keuangan yang lain akan mengikuti. Dengan mempertahankan penjualan aset properti maka perusahaan akan terus mendapatkan pendapatan. Semakin lama keuntungan perusahaan akan meningkat dan kinerja keuangan semakin bagus. Kinerja keuangan yang bagus akan menaikkan nilai rasio keuangan yang lain seperti NPM karena penjualan dan pendapatan bertambah. Selain itu rasio keuangan $R O E$ juga akan meningkat karena modal perusahaan untuk membiayai usahanya meningkat, semakin tinggi modal perusahaan maka kemampuan perusahaan untuk membuat unit properti baru juga bertambah, Kenaikan nilai $\mathrm{ROA}$ juga akan diikuti dengan kenaikan nilai EPS, dengan bertambahnya pendapatan yang didapat akan menaikkan laba per saham yang akan didapat oleh investor. Selain itu nilai DER dan BVS 
juga akan mengalami perubahan. Naiknya pendapatan membuat perusahaan berani untuk berhutang, berhutang sendiri akan menambah modal untuk membuat unit properti baru. Nilaj claim atau jamian saham yang dibeli oleh investor juga bertambah dengan naiknya nilai BVS. Dengan membaiknya kinerja perusahaan maka perusahaan dinyatakan dalam kondisi yang bagus, yang pada akhirnya akan menaikkan harga sahamnya di pasar saham. Tingginya harga saham menyebabkan risiko sistematik yang dihadapi oleh investor juga akan semakin tinggi.

Kondisi pasar yang tidak stabil membuat investor membeli saham hanya untuk mencari keuntungan melalui capital gain atau laba yang diperoleh dari harga jual dikurangi harga beli dikali jumlah saham. (Hidayat, 2011: 89).

Berpengaruhnya ROA terhadap harga saham didukung oleh penelitian yang dilakukan oleh Yusi (2011) dan Nirohito (2009) yang menyatakan bahwa ROA memiliki pengaruh terhadap harga saham. Variabel NPM tidak memiliki pengaruh terhadap harga saham, hal ini mendukung penelitian dari Sari, Safitri, Ekawati (2011) yang menyatakan variabel NPM tidak memiliki pengaruh terhadap harga saham.

Variabel EPS dan Risiko Sistematik (Beta) tidak memiliki pengaruh terhadap harga saham mendukung penelitian Anwar (2008) yang menyatakan EPS dan Risiko Sistematik (Beta) tidak memiliki pengaruh terhadap harga saham. Tidak berpengaruhnya ROE terhadap harga saham mendukung hasil penelitian Yusi (2011) yang menyatakan ROE tidak memiliki pengaruh terhadap harga saham. Variabel DER tidak memiliki pengaruh terhadap harga saham mendukung penelitian Uli (2008) dimana pada penelitiannya DER tidak memiliki pengaruh terhadap harga saham. Sedangkan tidak berpengaruhnya BVS mendukung penelitian dari Nirohito (2009) yang menyatakan BVS tidak memiliki pengaruh terhadap harga saham.

\section{Kesimpulan dan Saran \\ 4.1 Kesimpulan}

Secara parsial variabel independen yang memiliki pengaruh positif terhadap harga saham properti hanya variabel Return On Asset (ROA), sedangkan variabel yang lain seperti Net Profit Margin (NPM), Return On Equity (ROE), Debt To Equity Ratio (DER), Earning Per Share (EPS), Book Value Per Share (BVS), dan Risiko Sistematik (Beta) tidak memiliki pegaruh positif maupun negatif terhadap harga saham properti. Hal ini menunjukkan bahwa dalam perusahaan properti, perputaran aset lah yang sangat mempengaruhi kinerja keuangan perusahaan. Karena melalui penjualan aset properti, perusahaan dapat bertahan meskipun perekonomian sedang mengalami krisis.

\subsection{Saran}

Berdasarkan keterbatasan-keterbatasan yang telah dijelaskan, maka berikut adalah saran yang diberikan bagi penelitian yang akan datang:

1) Menambah variabel rasio keuangan lain yang kemungkinan memiliki pengaruh terhadap harga saham.

2) Menggunakan atau menambahkan faktor fundamental yang lain seperti tingkat suku bunga, tingkat inflasi, nilai tukar rupiah, dll yang kemungkinan memiliki pengaruh terhadap harga saham.

\section{DAFTAR PUSTAKA}

Abidin, Jamalul (2009), Analisis Faktor Fundamental Keuangan dan Risiko Sistematik Terhadap Harga Saham Perusahaan Consumer Goods yang Terdaftar di Bursa Efek Indonesia. Universtas Sumatera Utara Medan : Tesis.

Anwar, Solichin (2008), Pengaruh Faktor Fundamental dan Risiko Sistematik terhadap Harga Saham Perusahaan Sektor Penbiayaan di BEI Tahun 2007-2008. Universitas Gunadarma : Jurnal.

Atmaja, Lukas Setia. (2008), Teori \& Praktk Manajemen Ketiangan. Yogyakarta : ANDI.

Blocher, Edward J; Chen, Kung H; Cokins, Gary; Lin, Thomas W. (2007), Manajemen Biaya Penekanan Strategis, Edisi 3 Buku 2, (Terjemahan), Jakarta : Salemba Empat

Brealey, Myers, Marcus. (2007), Dasar-Dasar Manajemen Kenargan Perusahaan, (Terjemahan), Erlangga.

Darmadji, Tjiptono dan Fakhruddin, Hendy M. (2011), Pasar Modal di Indonesia Edisi 3. Jakarta : Salemba Empat.

Eftendi, Sofian. (2006), Merode Penelitian Strvey, Cetakan Kedelapan Belas, Edisi Revisi, Jakarta : PT Pustaka LP3ES Indonesia.

Fahmi, Irham. (2012), Pengantar Pasar Modal. Bandung : Alfabeta. 
Ghozali, Imam. (2009), Ekonometrika, Semarang : Badan Penerbit Universitas Diponegoro.

Ghozali, Imam. (2011), Aplikasi Analisis Multivariate dengan Program IBM SPSS 16. Edisi 5. Semarang : Badan Penerbit Universitas Diponegoro.

Hanafi, Mamduh M dan Halim, Abdul. (2009), Analisis Laporan Ketangan. Yogyakarta : Sekolah Tinggi llmu Manajemen YKPN.

Harahap, S.S. 2007. Teori Akuntansi. Jakarta : PT, Raja Grafindo Persada.

Halim, Abdul. (2005), Analisis Investasi, Edisi Kedua. Jakarta : Salemba Empat.

Hidayat, Taufik. (2011), Buku Pintar Investasi Reksa Dana, Saham, Opsi Saham, Valas \& Emas. Jakarta : Mediakita.

Hijriah, Almas. (2007), Pengaruh Faktor Fundamental dan Risiko Sistematik terhadap Harga Saham Properti di Bursa Efek Jakarta. Universitas Sumatera Utara : Tesis.

http:/bisnisproperti.com/2011/08/31/kenapamemilih-bisnis-properti/

http://finance.detik.com/read/2009/04/15/120601/11 15753/5/kronologi-dan-latar-belakang-krisisfinansial-globa!

http://finance.yahoo.com/

http://id.wikipedia_org/wiki/Ciputra_Development

http://id.wikipedia.org/wiki/Ciputra_Property

http://peluangbisnisproperty, wordpress.com/tag/pelu ang-bisnis-properti-tetap-menggiurkanprospek-bisnis-properti-masih-sangatmenjanjikan-di-2012-dan-bakal-boomingpada-2014-selain-ekonomi-yang-membaikdan-demand-masyarakat-yang-besar/

http:/properti.kompas.com/read/2008/10/23/103731 52/Bisnis.Properti,Sudah.Kebal.Krisis

http://tempo.co.id/ang/min/02/45/ekbisl.htm

http:/www.carajadikaya.com/analisa-peniliansaham-nilai-yang-berkaitan-dengan-saham/

http://www.duniainvestasi.com/bei/prices/stock/CO MPOSITE

http://www.idx.co,id/

http://www. livingestate, rumahkuonline.com/index.php?option $=$ com content\&ta $\underline{s k}=$ view\&id $=148 \&$ Itemid $=99999999$

http://www.mncland.com

http://www.suarapembaruan.com/ekonomidanbisnis/ 2012-tahun-kebangkitan-bisnis-properti/17626 hup://www theglobalreview.com/content detail.php?lang=id\&id=11 $25 \&$ type $=6$

Infobank. (2012), Artikel: Masih Akan Tumbuh Double Digit. Jakarta : PT. Infoarta Pratama.

Jogiyanto. (2009), Teori Portofolio dan Analisis Investasi, Edisi Keenam. Yogyakarta : BPFE.

Kamaludin dan Indriani, Rini. (2012), Manajemen Keuangan "Konsep Dasar dan Penerapannya" Edisi Revisi. Bandung : CV. Mandar Maju.

Kodrat, David Sukardi dan Indonanjaya, Kurniawan. (2010), Manajemen Investasi Pendekatan Teknikal dan Fundamental untuk Analisis Saham. Yogyakarta : Graha Ilmu.

Kuncoro, Mudrajad. (2007), Metode Kuantitatif Teori \& Aplikasi Untuk Bisnis \& Ekonomi. Yogyakarta : UPP STIM YKPN.

Laporan Keuangan 2008-2011. Indonesia Stock Exchange, Bursa Efek Indonesia : Semarang

Lasni, Ledi. (2008), Analisis Faktor Fundamental dan Risiko Sistematik terhadap Harga Saham pada Industri Dasar dan Kimia di Bursa Efek Indonesia (BEI). Universitas Gunadarma : Jurnal.

Lind, Douglas; Marchal, William G; Wathen, Samuel A. (2007), Teknik2 Statistik dalam Bisnis dan Ekonomi 2 (ed.13). Jakarta : Salemba Empat.

Martono dan Harjito, D. Agus. (2008), Manajemen Keuangan, Yogyakarta: Ekonisia.

Maryati, Kun. (2007), Sosiologi SMA Jilid 3 (KTSP). Erlangga.

Murhadi, Werner R, (2009), Analisis Saham Pendekatan Fundamental. Jakarta Barat : PT Indeks.

Nasehudin, Toto Syatori dan Gozali, Nanang. (2012), Metode Penelitian Kuantitatif. Bandung : CV Pustaka Setia.

Nirohito, Vernande. (2009), Analisis Pengaruh Faktor Fundantental dan Risiko Sistematik terhadap Harga Saham pada Industri Properti dan Real Estate di Bursa Efek Indonesia. Universitas Gunadarma : Jurnal.

Nurbaiti., Ritonga, Kirmizi., Anisma, Yunieta. (2010), Pengaruh Likuiditas, Solvabilitas, dan Profitabilitas terhadap Harga Saham pada Perusahaan Farmasi dan Kimia yang Go Publik di Bursa Efek Indonesia. Jurnal

Pasaribu, Rowland Bismark Femando. (2008), Pengaruh Variabel Fundamental Terhadap 
Harga Saham Perusahaan Go Public Di BEI. Jurnal Ekonomi dan Bisnis Vol 2, No. 2.

Patriawan, Dwiatma. (2010), Analisis Pengaruh Earning Per Share (EPS), Return On Equity (ROE), dan Debt To Equity Ratio (DER) terhadap Harga Saham Pada Perusahaan Wholesale and Retail Trade yang Terdaftar di Bursa Edek Indonesia (BEI) Tahun 2006-2008. Jurnal

Pujiyatmoko, Yohanes. (2010), Pengaruh Return On Asset, Return On Equity, Earning Per Share, dan Economic Value Added terhadap Harga Saham Perusahaan Property dan Real Estate. Universitas Gunadarma : Jurnal.

Ritonga, Dadang Fahruzi dan Akhmad, Arifin. (2012), Analisis Pengaruh Faktor Fundamental Keuangan Terhadap Harga Saham Perusahaan Publik Sektor Perdagangan Di Bursa Efek Indonesia. Universitas Sumatera Utara : Jurnal.

Riyanto, Bambang. (2008), Dasar-dasar Pembelajaran Perusahaan, Yogyakarta : BPFE.

Rizkiansyah, Achmad. (2010), Analisis Pengaruh ROA, ROE, NPM, dan EPS terhadap Harga Saham Perusahaan Pada Sektor Industri Barang Konsumsi di Bursa Efek Indonesia Periode 2008-2010. Universitas Gunadarma : Jurnal.

Samsul, Mohamad. (2006), Pasar Modal dan Manajemen Portofolio. Erlangga.

Santosa, Antonius Heru dan Setiawan, Aris Budi. (2008), Analisis Risiko Investasi Saham pada Sektor Properti di Bursa Efek Indonesia Periode 2003-2008. Universitas Gunadarma : Jurnal.

Sari, Ema Indah., Safitri, Ervita., dan Ekawati, Rika Kharlina. (2011), Pengaruh Faktor-Faktor Fundamental Terhadap Harga Saham PT Unilever Indonesia Tbk. STIE MDP : Jumal.

Santoso, Singgih. (2010), Statistik Multivariat. Jakarta : Elex Media Komputindo.

. (2011), Mastering SPSS Versi 19. Jakarta : PT Elex Media Komputindo.

Sartono, Agus. (2010), Manajemen Keuangan Teori dan Aplikasi. Yogyakarta : BPFE.

Saworno, Jonathan. (2006), Analisis Data Penelitiant Mengganakan SPSS. Yogyakarta: C.V Andi Offset.
Simamora, Bilson. (2005), Analisis Multivariat. Jakarta : Gramedia Pustaka Utama.

Stella. (2009), Pengaruh Price To Earnings Ratio, Debr To Equity Ratio, Return On Asset, dan Price To Book Value Terhadap Harga Pasar Saham. STIE Trisakti : Jurnal.

Soeratno dan Arsyad, Lincoln. (2008), Metodologi Penelitian Untuk Ekonomi \& Bisnis. Yogyakarta : Sekolah Tinggi limu Manajemen YKPN.

Sugiyono. (2009). Metode Penelitian Kuantitatif dan Kualitarif. Bandung : CV Alfabeta

Suhadi, Deddy A. (2007), Pergerakan Harga Saham Sektor Properti Bursa Efek Jakarta Berdasarkan Kondisi Profitabilitas, Suku Bunga, dan Beta Saham. Universitas Terbuka : Jurnal.

Sujarweni, V. Wiratna dan Endrayanto, Poly. (2012), Statistika Untuk Penelitian. Yogyakarta: Graha Ilmu.

Susilo, Bambang. (2009), Pasar Modal Mekanisme Perdagangan Saham, Analisis Sekturitas, Dan Strategi Investasi Di B.E.I. Yogyakarta : UPP STIM YKPN Yogyakarta.

Sutrisno, (2009), Manajemen Kewangan Teori. Konsep, dan Aplikasi. Yogyakarta : Ekonisia.

Tanjung, Alfitriady Amries Rusli dan Darlis, Edfan. (2009), Pengaruh EVA, ROA, ROE, ROS, EPS, BEP Terhadap Harga Shaham Peusahaan Perbankan dan Asuransi Di Bursa Efek Indonesia Tahun 2007-2009. Jurnal

Uli, Annisa Yunita. (2008), Analisis Pengaruh Faktor Fundamental dan Risiko Sistematik terhadap Harga Saham pada Perusahaan Sektor Industri Barang Konsunsi di BEI. Universitas Gunadarma : Jurnal.

Wijaya, Tony. (2009), Analisis Data Penelitian Menggunakan SPSS. Yogyakarta : Universitas Atma Jaya Yogyakarta.

Yusi, M Syahirman. (2011), Faktor Fundamental dan Risiko Sitemik Implikasinya Terhadap Harga Saham. Politeknik Negeri Sriwijaya Palembang : Jurnal. 